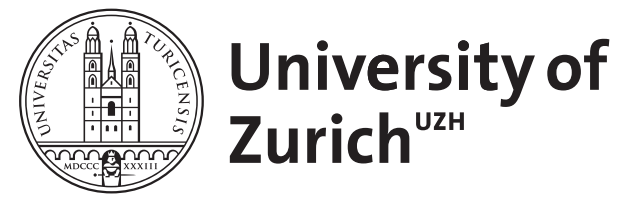
Archive

University of Zurich

University Library

Strickhofstrasse 39

CH-8057 Zurich

www.zora.uzh.ch

Year: 2019

International law in the best of all possible worlds - an introduction to G.W. Leibniz's theory of international law

Altwicker, Tilmann

DOI: https://doi.org/10.1093/ejil/chz010

Posted at the Zurich Open Repository and Archive, University of Zurich ZORA URL: https://doi.org/10.5167/uzh-186100

Journal Article

Accepted Version

Originally published at:

Altwicker, Tilmann (2019). International law in the best of all possible worlds - an introduction to G.W.

Leibniz's theory of international law. European Journal of International Law, 30(1):137-158.

DOI: https://doi.org/10.1093/ejil/chz010 
This is a pre-copyedited, author-produced PDF of an article accepted for publication in the European Journal of International Law (EJIL) following peer review. The version of record International Law in the Best of All Possible Worlds - An Introduction to G.W. Leibniz's Theory of International Law, European Journal of International Law [EJIL] 30 (2019), 137158, DOI: $10.1093 /$ jil/chz010 is available online at: https://academic.oup.com/ejil/articleabstract/30/1/137/5498090?redirectedFrom =fulltext.

\title{
International Law in the Best of All Possible Worlds: An Introduction to G.W. Leibniz's Theory of International Law
}

Tilmann Altwicker*

\begin{abstract}
Today, the contribution by Gottfried Wilhelm Leibniz (1646-1716), the last 'universal genius' to the theory of international law is nearly forgotten. Leibniz was a lawyer by training (later in life holding prestigious positions such as Reichshofrat), and he acted as a diplomat and political advisor to the duke of Hanover. His engagement with legal practice distinguishes Leibniz from other philosophers. Always looking for intellectual synergies, Leibniz integrated his knowledge of (positive) law into his legal theory. He provides the rare combination of an international legal theory that is both grounded in his metaphysics and natural law theory and inspired by his extensive study of the positive international law of his time (Leibniz was the first to systematically collect and analyse historical international treaty law). This article introduces Leibniz's theory of international law by outlining the different conceptual layers of his notion of ius gentium, by explaining the functions of natural law for positive international law and by showing how natural law can shape the substance of international relations. The three takeaways from Leibniz for contemporary international legal theory are the idea of
\end{abstract}

\footnotetext{
* Swiss National Science Foundation (SNSF)-Professor for Public Law, International Law, Legal Philosophy and Empirical Legal Research, University of Zurich, Switzerland. Email: tilmann.altwicker@rwi.uzh.ch. I am grateful for generous support of the SNSF. I thank two anonymous reviewers for exceptionally detailed and helpful comments. The usual disclaimer applies.
} 
optimizing pluralism, his ideas on synergies between theory and practice and, finally, his insistence on treating law as 'legal science'.

\section{Introduction: Leibniz's Forgotten Legacy to International Legal Theory}

Gottfried Wilhelm Leibniz's (1646-1716) contribution to the theory of international law is almost forgotten. ${ }^{1}$ This scholarly neglect stands in contrast to his continued presence in other fields; Leibniz is remembered for his contributions to mathematics (for example, as one of the inventors of calculus), to metaphysics (for example, for his concept of monads and preestablished harmony) and to philosophical theology (for example, his account of the problem of evil in the world). ${ }^{2}$ His legal philosophy in general does not enjoy similar scholarly attention. ${ }^{3}$ This is unfortunate because Leibniz was a lawyer by training who (other than Immanuel Kant, for example) valued the knowledge of positive law and integrated this knowledge into his legal theory. In consequence, Leibniz offers a more differentiated, more practice-oriented legal theory than many other philosophers.

Leibniz's career as a jurist and his involvement in international political events during his lifetime provided him with ample opportunity and cause to engage with international relations and law. ${ }^{4} \mathrm{He}$ was a witness to world-changing events that altered the course of international relations of his time and beyond; Leibniz was born in 1646, two years before the Peace of Westphalia ended the Thirty Years' War (in 1648), marking an 'epoch in the evolution

\footnotetext{
${ }^{1}$ Contemporary works on international legal theory make virtually no references to Leibniz. For example, the following otherwise highly useful volumes lack a contribution on Leibniz. A. Orakhelashvili (ed.), Research Handbook on the Theory and History of International Law (2011); B. Fassbender and A. Peters (eds), The Oxford Handbook of the History of International Law (2012); S. Kadelbach, T. Kleinlein and D. Roth-Isigkeit (eds), System, Order, and International Law: The Early History of International Legal Thought from Machiavelli to Hegel (2017). Almost no mention of Leibniz is made in P.-M. Dupuy, P. Haggenmacher and V. Chetail (eds), The Roots of International Law: Les fondements du droit international: Liber amicorum Peter Haggenmacher (2013). ${ }^{2}$ For a brief introduction to these topics and Leibniz's philosophy, see R.T.W. Arthur, Leibniz (2014), at 1; M. R. Antognazza, Leibniz (2016); B. Look, Gottfried Wilhelm Leibniz (2013), available at https://plato.stanford.edu/archives/sum2017/entries/leibniz/.

${ }^{3}$ But see, exceptionally, P. Riley, Leibniz' Universal Jurisprudence (1996); C. Johns, The Science of Right in Leibniz's Moral and Political Philosophy (2013) (in addition to a commentary, Johns provides a helpful English translation of parts of Leibniz's Nova Methodus Discendae Docendaeque Jurisprudentia, infra note 77). For overviews, see Armgardt, 'Leibniz as a Legal Scholar', 20 Fundamina (2014) 27; Artosi and Sartor, 'Leibniz as Jurist', in M.R. Antognazza (ed.), The Oxford Handbook of Leibniz (2018) 641.

${ }^{4}$ For Leibniz's biography, see M.R. Antognazza, Leibniz: An Intellectual Biography (2009); Arthur, supra note 2 , at 6-28.
} 
of international law'. ${ }^{5}$ Leibniz famously commented on the topical issue of sovereignty. ${ }^{6}$ Also, the consolidation of sovereign territorial powers in Europe fell in his lifetime as well as the gradual overlapping of traditional sources of legal ordering of international relations (rules of feudal law, constitutional rules of states and rules on succession) with the clear emergence of a positive law of nations. ${ }^{7}$ Leibniz was a thoroughly politically minded thinker who aimed at preserving peace within Europe through international law. ${ }^{8}$ But his engagement with international relations and law remained theoretical. For example, faced with the expansionist politics by King Louis XIV of France, Leibniz undertook great efforts (ultimately, in vain) to approach the French king and to divert his military action from Europe to Egypt in his (in)famous Egyptian Plan. ${ }^{9}$ Leibniz's reflections on politics and law were not limited to Europe but extended to countries as far as China and Russia and included their laws and customs. ${ }^{10}$ In his extensive writings, he commented on various issues pertaining to international relations (international conflicts, customs of war and peace negotiations, diplomacy, international trade, law of the sea and military alliances). ${ }^{11}$

Recently, there have been attempts to revive some of Leibniz's political ideas on ordering international relations. Interestingly, several accounts bring to bear Leibniz's political metaphysics on contemporary problems. For example, his notions of a civitas dei and of a 'balance of power' were suggested as precursors to a theory of federalism or even as a 'reference point' for the development of the European Union. ${ }^{12}$ Other authors rely on Leibniz's

\footnotetext{
${ }^{5}$ Gross, 'The Peace of Westphalia, 1648-1948', 42 American Journal of International Law (1948) 20, at 26 (in Gross' words, the Peace of Westphalia, stands for the 'laicization of international law by divorcing it from any particular religious background').

${ }^{6}$ See Leibniz, 'Caesarinus Fürstenerius (1677)', in Deutsche Akademie der Wissenschaften zu Berlin (ed.), Gottfried Wilhelm Leibniz: Sämtliche Schriften und Briefe (1677-1687) (2nd edn, 1984), vol. 4, part 2, 3.

${ }^{7}$ On these developments, see Steiger, 'Rechtliche Strukturen der Europäischen Staatenordnung 1648-1792', 59 Zeitschrift für ausländisches öffentliches Recht und Völkerrecht (1999) 609.

${ }^{8}$ See Leibniz, supra note 6, at 140: 'Hujus gentium juris summa ratio est, ut bella evitentur' ['The gist of international law is to avoid wars'] (translation by the author).

${ }^{9}$ See Antognazza, supra note 4, at 124, 140, 146.

${ }^{10}$ Nijman, 'A Universal Rule of Law for a Pluralist World Order: Leibniz's Universal Jurisprudence and His Praise of the Chinese Ruler', in A. Carty and J.E. Nijman (eds), Morality and Responsibility of Rulers: European and Chinese Origins of the Rule of Law as Justice for World Order (2017) 222, at 237-244 (on China). There are more than 600 references to China in Leibniz's writings, as a query in the Leibniz database by the BerlinBrandenburg Academy of Sciences and Humanities reveals (available at http://telota.bbaw.de/leibniziv/Sachregister/sachreg_fragen.php?aktion=schlagwort\&eins=China\&band=) and more than 200 to $\quad$ Russia (available http://telota.bbaw.de/leibniziv/Sachregister/sachreg_fragen.php?aktion=schlagwort\&eins=Russland\&band=).

11 A query in the Leibniz database by the Berlin-Brandenburg Academy of Sciences and Humanities resulted in 81 hits for the term 'Völkerrecht', including the topics mentioned above (available at http://telota.bbaw.de/leibniziv/Sachregister/sachreg_fragen.php?aktion=schlagwort\&eins=V\%F6lkerrecht\&band $=$ ).

12 See Basso, 'Regeln einer effektiven Außenpolitik: Leibniz' Bemühen um eine Balance widerstreitender Machtinteressen un Europa', 40 Studia Leibnitiana (2008) 139, at 151. For an even more progressive adaptation
} 
metaphysics of monads and pre-established harmony in order to account for the political ideal of a balance of power. ${ }^{13}$ Certainly, the question of ordering states poses more than a political problem; for Leibniz, the stability of the international order of states (or sovereigns) depends on its conformity with natural law, ethics, metaphysics and political theology. ${ }^{14}$ Similarly, metaphysics and law cannot be considered in isolation when dealing with Leibniz. In a typically rationalist fashion, Leibniz argues that the human intellect is capable of having, albeit limited, insight in the 'nature of things' and into the 'eternal laws of nature'. ${ }^{15}$ Leibniz's theory of natural law - which also fulfils several functions in respect of international law - is ultimately grounded in his 'metaphysics of possible entities'. ${ }^{16}$ The title of this contribution, 'international law in the best of all possible worlds', attempts to reflect these metaphysical foundations of Leibniz's theory of international law. As with Leibniz's political metaphysics, it would be a worthwhile undertaking to 'restore' his legal metaphysics for analytical purposes concerning current international legal problems ${ }^{17}$ However, given the mainly reconstructive focus of the present article, this must be left largely to further research. The present contribution only offers some hints as to where contemporary international legal theory could benefit from Leibnizian metaphysics (in particular, the particularism/universalism problem and the idea of an international legal science). ${ }^{18}$

Unlike his political projects, Leibniz's conception of international law has rarely been studied with systematic interest, and the peculiarities of his conception of international law have largely been ignored in the literature. ${ }^{19}$ The neglect of Leibniz's ideas on international law is far from a novel phenomenon. Already in its earliest phase of reception, Leibniz's treatment of international law was critically commented upon by Christian Wolff and Emer de

of Leibniz's political thought (however, excluding international relations) to modern times, see Salas, 'A Leibnizian Vision of Our Times: Politics and Theodicée in the Current Political Scene', 40 Studia Leibnitiana (2008) 125. For a more historicizing approach, see Beiderbeck, 'Leibniz's Political Vision for Europe', in M.R. Antognazza (ed.), The Oxford Handbook of Leibniz (2013), available at http://www.oxfordhandbooks.com. For the relationship of 'civitas dei' and 'balance of power', see Roldán, 'Perpetual Peace, Federalism and the Republic of the Spirits: Leibniz between Saint-Pierre and Kant', 43 Studia Leibnitiana (2011) 87; Basso, supra note 12.

${ }^{13}$ Nitschke, 'Gottfried Wilhelm Leibniz: Die Einheit in der Vielfalt: Zur Politologie der Staatenwelt', in J. Bellers (ed.), Klassische Staatsentwürfe: Außenpolitisches Denken von Aristoteles bis heute (1996) 89.

${ }^{14}$ See Nitschke, 'Die Leibnizsche Vision von Europa', in P. Nitschke (ed.), Gottfried W. Leibniz: Die richtige Ordnung des Staates (2015) 91, at 105.

${ }^{15}$ On Leibniz's theory of knowledge, see Antognazza, supra note 2, at 49-61.

${ }^{16}$ M.-T. Liske, Gottfried Wilhelm Leibniz (2000), at 190. On the functions of natural law in the present context see Part 3 in this article.

${ }^{17}$ For some recent attempts, see notes 22 and 24 below.

${ }^{18}$ See Part 5 in this article.

${ }^{19}$ For example, Leibniz's writings on international law are not included in the series Classics of International Law (edited by James Brown Scott). 
Vattel (who otherwise held him in high esteem) ${ }^{20}$ However, in more recent times four aspects of Leibniz's conception of international law did gain scholarly attention. In the 1940s, Paul Schrecker interpreted Leibniz's philosophy of international law as a contribution to the 'rationalization of international relations'. ${ }^{21}$ More recently, in her work The Concept of International Legal Personality (2004), Janne Nijman discussed Leibniz as the first writer to develop a concept of an 'international legal person'. ${ }^{22}$ From the perspective of international legal history, Heinhard Steiger examined Leibniz's notion of sovereignty and the concept of ius suprematus. ${ }^{23}$ From yet another angle, Thomas Kleinlein argued that Leibniz's discussion of the civitas dei should be read as a precursor to modern constitutionalism. ${ }^{24}$ What is currently lacking is an appreciation of Leibniz's treatment of international law as a distinct conceptual and theoretical achievement and as an integral part of his legal science.

On the whole, therefore, it seems fair to say that Leibniz's ideas on international law are unknown to today's international legal scholars. There are four principal reasons for the neglect of Leibniz's conception of international law. The first practical reason is that there is a problem with the accessibility of primary sources. Several texts of Leibniz's enormous literary work are only available in Latin or French, and reliable English translations, especially of those parts concerning international law, are lacking. ${ }^{25}$ A second obstacle is the fact that law for Leibniz is part of his system of metaphysics, as already stated above. Leibniz's legal philosophy is considered by Alfred Verdross as the 'culmination and endpoint of occidental legal metaphysics'. ${ }^{26}$ Relying on Leibnizian metaphysics today seems odd or - following

${ }^{20}$ C. Wolff, Jus Gentium Methodo Scientifica Pertractatum (1749), at 13 (§ 16); E. de Vattel, Le Droit des Gens (1758), at 44 (\$ 46). See T. Toyoda, Theory and Politics of the Law of Nations (2011), at 99-100 (referring to Wolff's criticism on Leibniz's conception of sovereignty and Vattel's criticism of the right to absolute rule). For Leibniz's influence on Wolff and Vattel, see Holland, 'The Moral Person of the State: Emer de Vattel and the Foundations of International Legal Order', 37 History of European Ideas (2011) 438.

${ }^{21}$ Schrecker, 'Leibniz's Principles of International Justice', 7 Journal of the History of Ideas (1946) 484, at 496.

22 J.E. Nijman, The Concept of International Legal Personality (2004), at 29-84.

${ }^{23}$ Steiger, 'Supremat: Außenpolitik und Völkerrecht bei Leibniz', in F. Beiderbeck, I. Dingel and W. Li (eds), Umwelt und Weltgestaltung: Leibniz' politisches Denken in seiner Zeit (2015) 135.

${ }^{24}$ T. Kleinlein, Konstitutionalisierung im Völkerrecht (2012), at 261-271.

${ }^{25}$ A useful starting point for research on Leibniz is the digital Leibniz Bibliography, a database containing more than 30,000 titles of global research on Leibniz (also searchable in English), available at www.leibnizbibliographie.de. To search within Leibniz's works, see http://telota.bbaw.de/leibniziv/Sachregister/sachreg_start.php (in German). Some English translations of Leibniz's texts on international law are contained in G.W. Leibniz (ed.), Political Writings (2nd edn, 1988) (containing excerpts of the Caesarinus Fürstenerius, the preface to the Codex Iuris Gentium and several writings on natural law). The original texts are successively edited as Akademie-Ausgabe by the Berlin-Brandenburg Academy of Sciences and the Academy of Sciences Göttingen, available at https://leibnizedition.de/de/. As part of this series, the political writings are available at http://leibniz-potsdam.bbaw.de/.

${ }^{26}$ Verdross, 'Höhepunkt und Abschluss der abendländischen Rechtsmetaphysik bei Leibnitz', Völkerrecht und Rechtsphilosophie: internationale Festschrift für Stephan Verosta zum 70. Geburtstag (1980) 461. 
Kant's footsteps - even impossible. ${ }^{27}$ For many scholars, therefore, Leibnizian ideas inevitably represent outdated, backward-looking thinking. Third, some scholars stress the bond between Leibniz's conception of international law and his political aspirations, some of which appear troubling from a contemporary perspective. The insignificance of Leibniz's conception of international law, today, in this perspective, is due to his untenable political ideas - for example, his already mentioned Egyptian Plan (whereby France should occupy Egypt instead of waging war in Europe), his obstinate defence of the Holy Roman Empire or his advocacy for a 'world domination of the Christian church'. ${ }^{28}$ These political propositions - sacrificing others to spare your own, propagation of the Reichsidee, dominance of the Christian faith seem hardly reconcilable with the idea of diversity inherent in the notion of the 'best of all possible worlds'. However, it should be noted that Leibniz's conception of 'the best of all possible worlds' is a purely rational construction (following from his philosophical theology), which is neither susceptible to empirical proof nor to falsification. ${ }^{29}$ As Maria Rosa Antognazza states, 'the best possible world is the world in which there is the greatest possible combination of things, with all their perfections (that is, positive qualities), in all their varieties' ${ }^{30}$ Given our finite (though gradually perfectible knowledge) of the world, an individual act cannot be judged under this perspective. ${ }^{31}$ Relatedly, fourth, the usurpation of Leibniz's political ideas during the time of National Socialism in Germany - for example, by the constitutional lawyer Ernst Rudolf Huber - may have also contributed to the present situation of neglect. ${ }^{32}$

In contrast to these positions, the present article argues that Leibniz's analysis of the foundations of 17th-century international law, his theory-driven, systematic engagement with positive international law and his methodological approach clearly have something to offer to international legal theory, which has, so far, largely been overlooked. The article, thus, aims to introduce Leibniz's conception of international law and to elucidate the connections with his

\footnotetext{
${ }^{27}$ Peter Strawson famously phrased Kant's point thus: '[I]t is evident that, on any interpretation of the critical doctrine, the curtain of sense cuts us empirical beings irrevocably off from any knowledge of things as they are in themselves.' Strawson, 'The Problem of Realism and the a Priori', in P.F. Strawson (ed.), Entity and Identity: and Other Essays (2000) 244, at 251.

${ }^{28} \mathrm{~F}$. Cheneval, Philosophie in weltbürgerlicher Bedeutung (2002), at 51.

${ }^{29}$ Schepers, 'Ist Unsere die Beste der Möglichen Welten?: Was fordert Leibniz zur Affirmation seiner These?', 42 Rechtstheorie (2011) 1, 19.

${ }^{30}$ Antognazza, supra note 2, at 65.

${ }^{31}$ Instead, the morality of individual acts, including international law-making and transnational acts by sovereigns, is to be judged on the basis of a set of universal ethical principles. See Part 4 in this article.

${ }^{32}$ See, e.g., Huber, 'Reich, Volk und Staat in der Reichsrechtswissenschaft des 17. und 18. Jahrhunderts', 102 (1941-1942) Zeitschrift für die gesamte Staatswissenschaft (1941) 593, at 600 (claiming that in Leibniz one finds a 'powerful flare-up of a real and convinced Reichs-patriotism, aiming unerringly at the restoration of German unity, greatness and power') (translated by the author); see also W. Li (ed.), "Leibniz" in der Zeit des Nationalsozialismus (2013).
} 
theory on natural law. The present article, therefore, focuses on Leibniz as a lawyer-scientist. ${ }^{33}$ It proceeds as follows: first, Leibniz's understanding of the term 'international law' is explained; second, the intricate relationship between natural law and international law in Leibniz is examined; third, the relevance of Leibniz's three stages of natural law for international law is considered and, fourth, the article concludes on what Leibniz's conception of international law has to offer to contemporary international legal theory: the idea of optimizing pluralism, the notion of theoria cum praxi and the idea of approaching (international) law as legal science.

\section{Ius Naturae, Ius Gentium Voluntarium and Ius Gentium Europaearum: Conceptual}

\section{Layers of International Law}

Leibniz uses a multi-layered concept of international law. The conceptual complexity is due to Leibniz's ambition to bridge the universalist ambition of international law with particularist notions of law binding certain nations (or sovereigns). Indeed, in his writings, he employs several expressions for 'international law'. As was common in the 17th century, the term ius gentium is most frequently encountered in his writings on international law. ${ }^{34}$ However, like his contemporaries Samuel Pufendorf (1632-1694) and Christian Thomasius (1655-1728), Leibniz also uses the formula of ius naturae et gentium. ${ }^{35}$ In one (important) instance, Leibniz also speaks of ius faecialis inter Gentes. ${ }^{36}$ These formulations reflect the major debates surrounding the notion of international law in Leibniz's times; the first concerns a problem of scope - namely, the question whether 'international law' refers, as in the original Roman law meaning of the term, to the law that all nations have in common (ius gentium) or whether the concept of international law refers to legal relations between nations (ius inter gentes). The other major conceptual debate of Leibniz's time pertains to the question of the existence of positive international law besides natural law.

Regarding the question of scope, Leibniz seems to reserve fairly consistently the notion of 'international law' for legal relations between nations (or sovereigns). This is most evident

\footnotetext{
${ }^{33}$ On Leibniz's notion of a lawyer-scientist, see the quote accompanying note 152 below.

${ }^{34}$ Especially in Leibniz, supra note 6, at 39, 56, 140, 267.

35 See Leibniz, 'Praefatio Codicis Juris Gentium Diplomatici', in Deutsche Akademie der Wissenschaften zu Berlin (DAWB) (ed.), Gottfried Wilhelm Leibniz: Sämtliche Schriften und Briefe (1692-1694) (2004) vol. 5, part 4,48 , at 60,63 .

${ }^{36}$ Ibid., at 74 .
} 
when he uses the expression of ius faecialis inter Gentes. ${ }^{37}$ Here, Leibniz appears to refer to a work by Richard Zouche (circa 1590-1661) who, in 1650, had published a treatise with the title Iuris et Iudicii Faecialis, sive Iuris Inter Gentes. ${ }^{38}$ Zouche famously distinguished between the two layers of ius gentium and ius inter gentes. ${ }^{39}$ Though Leibniz may have had Zouche's work in mind, the concept of ius faecialis inter Gentes originates, of course, in Roman law. Tellingly, in Roman law, ius feciale denoted an (international) law of war and a law of heralds, grounded in religious rites and ceremonies of communities. ${ }^{40}$ Therefore, the ius feciale is considered a 'rudimentary species of international law'. ${ }^{41}$ Thus, when Leibniz speaks of ius faecialis inter Gentes, he in fact 'duplicates' the cross-border scope of international law. Furthermore, it was in Leibniz's time that the transition in meaning from ius gentium to ius inter gentes began to be more clearly reflected in legal practice - for example, through the acceptance of rules and principles on sovereign equality, the right to wage war and the privileges of ambassadors. ${ }^{42}$ Assumedly, Leibniz resorts to the imprecise, but widely used, concept of ius gentium because the expression ius faecialis inter Gentes was far less prevalent in his time.

Leibniz, who himself had served in diplomatic missions for his superiors (for example, in a successful intervention at the imperial court to grant electoral dignity to the duke of Hanover), was acquainted with the practice of international law, and, consequently, it must have appeared natural for him to associate ius gentium with the law pertaining to relations between nations/states or sovereigns. ${ }^{43}$ On the one hand, the fact that ius gentium relates to both nations/states and sovereigns follows naturally from the post-Westphalian international order; regarding its subject matter, some aspects of ius gentium (for example, aristocratic marriage contracts) relate to sovereigns, and some aspects to 'nations' or 'states' (for example,

\footnotetext{
${ }^{37}$ Ibid.

38 See B. Durst, Archive des Völkerrechts (2016), at 213, n. 132. On Richard Zouche, see Good, 'Völkerrechtsphilosophie der Frühaufklärung und die "Praktiker" des Völkerrechts', in T. Altwicker, F. Cheneval and O. Diggelmann (eds), Völkerrechtsphilosophie der Frühaufklärung (2015) 229, at 230-234. Jean Bodin had already used the concept of ius feciale in the sense of a 'public law of nations'. See Scattola, 'Jean Bodin on International Law', in Kadelbach, Kleinlein and Roth-Isigkeit, supra note 1, 78, at 83-84. I am grateful to an anonymous reviewer for pointing this out to me.

${ }^{39}$ For more details, see Good, supra note 38, at 232-233. Although disputed, the distinction can already be found in Francisco de Suárez and, as some argue, in the work of Francisco de Vitoria. See W.G. Grewe, The Epochs of International Law (2000), at 25-26 (discussing the various interpretations).

${ }^{40}$ H.S. Maine, Ancient Law (2005), at 31.

${ }^{41}$ H.C. Black, A Law Dictionary (2nd edn, 1995), at 677-678.

${ }^{42}$ See Steiger, supra note 7, at 621-622.

43 On Leibniz's diplomatic endeavours, see Schneider, 'Gottfried Wilhelm Leibniz', in M. Stolleis (ed.), Staatsdenker in der frühen Neuzeit (3rd edn, 1995) 197, at 211-213 (also on his unsuccessful Egyptian Plan).
} 
rules on diplomacy). ${ }^{44}$ On the other hand, the juxtaposition or duplication of the subjects of ius gentium is characteristic for Leibniz's conception of the international order. His political philosophy, in large part, is meant to demonstrate that the Holy Roman Empire, founded on the principles of balance of power and justice, is in fact an approximation of the ideal of the civitas $d e i{ }^{45}$ In Leibniz's ideal, the international order is not composed of a system of monolithic states with absolute sovereignty but, rather, a federal structuring of international relations, taking the Holy Roman Empire as a role model. ${ }^{46}$ This more complex, federal structuring of international relations allows for the 'relative sovereignty' (Janne Nijman) of its subjects, composed of a diverse set of actors - that is, nations, states, sovereigns (given their jus suprematus) ${ }^{47}$ Finally, Leibniz, who, in 1691, had become chief librarian of the Wolfenbüttel library, authored a classification of the scientific disciplines (for purposes of library organization) ${ }^{48}$ In this tabula, Leibniz explicitly distinguishes between the laws of the different nations (iura variarum gentium) and the law governing relations between nations (ius inter gentes). ${ }^{49}$

The other major conceptual debate concerns the different 'layers' of the law governing international relations. A first important layer of Leibniz's ius gentium concept is formed by natural law (ius naturae). In a telling passage, Leibniz accepts Thomas Hobbes' factual diagnosis that nations are involved in a permanent war with each other, but fiercely opposes Hobbes' normative conclusion - namely, that there is a natural right to harm other nations that is, a natural right to wage war. ${ }^{50}$ Leibniz must reject this normative conclusion because it stands in opposition to the neminem laedere ('do no harm') command, which is central to his natural law theory. ${ }^{51}$ Leibniz cunningly transforms the factual diagnosis that there is perpetual conflict between nations into a prudential argument to prepare for war. ${ }^{52}$ In contrast to Hobbes and Baruch Spinoza, Leibniz sides with Hugo Grotius (and the Spanish scholastics) who maintained that international relations formed a normative space $a b$ initio, that natural law (in

\footnotetext{
${ }^{44} \mathrm{I}$ am grateful to an anonymous reviewer for pointing this out to me.

${ }^{45}$ Beiderbeck, supra note 12.

${ }^{46}$ See Roldán, supra note 12, at 93-97.

${ }^{47}$ On Leibniz's treatment of the 'persona jure gentium', see Nijman, supra note 22, at 29-84.

48 Leibniz, 'Tabula de Ordinanda Bibliotheca (c. 1693)', in DAWB (ed.), Gottfried Wilhelm Leibniz: Sämtliche Schriften und Briefe (1692-1694) (2004) vol. 5, part 4, 635.

${ }^{49}$ Ibid., at 640.

${ }^{50}$ Leibniz, supra note 35, at 50-51. For an English translation, see Leibniz, supra note 25, at 166 (stating that 'the subtle author of the Elementa de Cive [Hobbes] drew the conclusion that between different states and people there is a perpetual war; a conclusion, indeed, which is not altogether absurd, provided that it refers not to a right to do harm, but to take proper precautions').

${ }^{51}$ See Part 4 in this article.

${ }^{52}$ See again the quotation in note 50 above.
} 
its form as ius strictum) is binding upon sovereigns as law (and, thus, is distinct from instrumental rules of prudence and distinct from a void 'natural right', as in Hobbes). ${ }^{53}$ Leibniz, in other words, rejects the Hobbesian idea that the existence of normativity in international relations requires an international social contract between sovereigns. For the anti-voluntarist Leibniz, it is clear that, already by virtue of 'eternal' natural law, there is a substantial set of obligations that sovereigns are bound to obey, most importantly the neminem laedere command. Considerable complexity in Leibniz's concept of international law results from the underlying natural law conception. In contrast to his contemporary, Samuel Pufendorf, Leibniz recognizes multiple 'stages' of natural law, stretching further than the neminem laedere command..$^{54}$

A second layer of the ius gentium concept in Leibniz relates to positive international law. As an experienced diplomat, Leibniz is unequivocal on the existence and use of this layer of law. In an important passage in the Praefatio Codicis Juris Gentium Diplomatici, Leibniz states that, just like there can be rules of civil law (ius civile) made by a superior domestically, there can also be man-made rules governing relations between nations; Leibniz calls the latter 'voluntary law of nations' (ius gentium voluntarium) ${ }^{55}$ Due to his anti-voluntarism (and, again, in visible contrast, for example, to Pufendorf), the de facto absence of a superior in international relations with a global legislating power is not a problem for Leibniz. ${ }^{56}$ The normativity of the voluntary law of nations, for Leibniz, does not derive from superior will but, rather, from its foundation in natural law (and, ultimately, for the believing Christian that he was, in God's intellect) ${ }^{57}$ More concretely, Leibniz explicitly acknowledges the two primary sources of positive international law: international treaties and customary international law. ${ }^{58}$ He knows

\footnotetext{
${ }^{53}$ On Hobbes' position, see Heller, 'Orders in Disorder: The Question of a Sovereign State of Nature in Hobbes and Rousseau', in Kadelbach, Kleinlein and Roth-Isigkeit, supra note 1, 160, at 178 (stating that, in Hobbes' account, 'the international sphere ... is an empty space from a legal point of view'). On Spinoza, see Altwicker, 'The International Legal Argument in Spinoza', in Kadelbach, Kleinlein and Roth-Isigkeit, supra note 1, 183, at 186-92 (emphasizing that, despite the absence of normativity in the international state of nature, Spinoza delineates the conditions under which international law is possible to exist).

54 On Pufendorf's conception of international law, see Fiorillo, 'States, as Ethico-Political Subjects of International Law: The Relationship between Theory and Practice in the International Politics of Samuel Pufendorf', in Kadelbach, Kleinlein and Roth-Isigkeit, supra note 1, 199, at 202.

${ }^{55}$ Leibniz, supra note 35, at 63-64. For an English translation, see Leibniz, supra note 25, at 174. By recognizing a voluntary law of nations, Leibniz follows Grotius. See Kadelbach, 'Hugo Grotius: On the Conquest of Utopia by Systematic Reasoning', in Kadelbach, Kleinlein and Roth-Isigkeit, supra note 1, 134, at 141.

${ }^{56}$ On Pufendorf's denial of the existence of positive international law, see Fiorillo, supra note 54, at 205; see also Steiger, 'Völkerrecht', in O. Brunner, W. Conze and R. Koselleck (eds), Geschichtliche Grundbegriffe: Historisches Lexikon zur politisch-sozialen Sprache in Deutschland (1993), vol. 7, 97, at 116.

${ }^{57}$ Leibniz, supra note 25, at 45-53 (from the Meditation on the Common Concept of Justice).

${ }^{58}$ Leibniz, 'Praefatio Mantissae Codicis Juris Gentium Diplomatici (c. 1700)', in DAWB (ed.), Gottfried Wilhelm Leibniz: Sämtliche Schriften und Briefe (1699-1700) (2015) vol. 8, part 4, 40, at 43-44 ('sunt illis pro legibus,
} 
that legal questions or conflicts arising in international relations are, in practice, not solved by reference to natural law principles but, instead, by reference to positive international law and by cunning legal reasoning based on these sources. ${ }^{59}$

Leibniz's impressive collection of historical international treaties in the Codex Juris Gentium Diplomaticus provides further evidence of his awareness of the importance of positive international law. ${ }^{60}$ Furthermore, Leibniz sees that positive international law in contrast to natural law is variable relative to time and place. ${ }^{61}$ As his own research (in the Codex Juris Gentium Diplomaticus) showed him, positive international law involves a certain plurality of legal rules. Not all international legal rules remain the same at all times and in all places. In other words, there is variability in positive international law both along a historical and a geographical axis. ${ }^{62}$ Regarding its subject matter, positive international law for Leibniz primarily concerns not only the law of alliances, the laws on war and peace and the law on cession but also the law of diplomats. By allowing for the existence of a 'voluntary law of nations', conceptually dissociated from both 'natural law' and 'domestic law', Leibniz's international law concept is less rigid than that of, for example, Pufendorf and, thus, is arguably more compatible with the fast-changing legal reality of his time (characterized by an increase in 'voluntary' international legal norms binding upon the sovereigns). ${ }^{63}$ Furthermore, the dissection of a voluntary part in the law-of-nations concept called for a specific international legal approach to matters such as diplomacy, treaty making and war. In contrast to Christian Thomasius, Leibniz treats questions of war and treaty making as legal problems, not as

quas ipsi sibi dixere; vel scriptis tabulis vel moribus introductis, qui saepe scripturis istis comprobantur') ['As laws, they (the nations) take what they have themselves accepted, either in the form of written charters or customs which are often confirmed by the written charters', translation by the author].

${ }^{59}$ Leibniz himself famously founded his argument in favour of a right of minor German princes to be treated as sovereigns partially on treaty law and customary law. See Leibniz, supra note 6; see also the quote on lawyerscientists in note 152 below.

${ }^{60}$ For a more critical view, see Nijman, supra note 22, at 75 (pointing to Leibniz's statement in the Codex Juris Gentium [see Leibniz, supra note 25, at 165-167] that the positive law does not reflect the secret intentions that sovereigns may sometimes have when concluding an international treaty). However, in my view, Leibniz's criticism of international law-making should rather be interpreted as criticism of the concrete historical treatymaking practice (which he seeks to improve), not as a critique of the institution of positive international law as such.

${ }^{61}$ Leibniz, supra note 35 , at 64; Leibniz, supra note 25 , at 174.

${ }^{62}$ In my view, Leibniz's clear awareness of a historical contingency in positive international law deserves further scholarly attention.

${ }^{63}$ On Pufendorf, see again Fiorillo, supra note 54, at 205-206, 210-211 (stating that Pufendorf considers treaties between states such as peace treaties not as manifestations of a law of nations but, rather, as 'private contracts'). On the consequences of Pufendorf's denial of a separate existence of the law of nations for the problem of state personality under international law, see Nijman, supra note 22, at 58. On the new role of international law by consensus, see O. Asbach and P. Schröder (eds), War, the State, and International Law in Seventeenth-Century Europe (2010), at 6 (speaking of a radical transformation, rationalization and secularization of international law starting in the mid-17th century). 
problems of politics or habitual behaviour. ${ }^{64}$ Thus, Leibniz's approach stands in continuity to the emancipation of a voluntary international law by Grotius. ${ }^{65}$ In sum, by being able to integrate the development of positive international law into his theory, Leibniz's approach proves more far-sighted than that by his voluntarist antipodes (especially Hobbes and Pufendorf). ${ }^{66}$

A third layer of Leibniz's ius gentium concept concerns what today would be called 'particular international law' - that is, legal rules that exclusively bind some, but not all, states or - in Leibniz's time - sovereigns. An obvious example for Leibniz was the ius gentium Europaearum, a European international law that was only binding upon European nations. ${ }^{67}$ European international law, according to Leibniz, is founded upon two sources: on the unifying influence of Roman law and on canon law (ius divinum positivum). The latter layer of law, according to Leibniz, is grounded in the sacred canons accepted by the whole Christian church and, in the West, by pontifical law to which all kings and peoples have submitted. ${ }^{68}$ Unfortunately, Leibniz does not spell out exactly the international legal relevance of ius divinum positivum.

In sum, Leibniz works with a multi-dimensional concept of international law, encompassing universal (ius naturae), voluntary (ius gentium voluntarium) and particularist elements (ius divinum positivium but also regional customary law). Therefore, already his concept of international law is of considerable complexity. When Leibniz speaks of ius gentium, he clearly refers to the 'modern' notion of an international law pertaining to the relations between nations and not to the older Roman law tradition of a law common to all nations.

\footnotetext{
${ }^{64}$ On Thomasius, see Koskenniemi, 'Transformations of Natural Law: Germany 1648-1815', in A. Orford, F. Hoffmann and M. Clark (eds), The Oxford Handbook of the Theory of International Law (2016) 59, at 65.

${ }^{65}$ See also - regarding Grotius - Nijman, supra note 22, at 48 (stating that a different method was required to identify the rules of the voluntary law of nations).

${ }^{66}$ On voluntarism in Hobbes and Pufendorf, see T.J. Hochstrasser, Natural Law Theories in the Early Enlightenment (2000), at 72-110. For a comparison of Leibniz and Pufendorf, see Goebel, 'The Equality of States', 23 Columbia Law Review (CLR) (1923) 247, at 276 (accusing Pufendorf of a 'complete lack of political realism and practical understanding of international affairs').

${ }^{67}$ Mentioned by Leibniz in Leibniz, supra note 58, at 66.

${ }^{68}$ Leibniz, supra note 35, at 64; Leibniz, supra note 25, at 174-175.
} 


\section{Basis Igitur Ius Naturae: International Trajectories of Natural Law}

Early Enlightenment legal philosophy faced a problem inherited from the Spanish scholastics (and also from Grotius), resurfacing with renewed force once the 'voluntary law of nations' gained importance: the proper relationship between natural law and international law. ${ }^{69}$ In modern terminology, the problem concerned the function of natural law in relation to international law. ${ }^{70}$ If natural law is thought of as 'eternal' and 'immutable', what is its impact on positive international law? Several different positions on this question were available in Leibniz's time. For example, Francisco de Vitoria had sought to derive, with different 'degrees of necessity', positive legal norms from natural law. ${ }^{71}$ Alberico Gentili and Johannes Oldendorp also had suggested a close relationship between international and natural law. ${ }^{72}$ Other accounts left room for a more complex relationship between ius gentium and ius naturale. For example, Fernando Vásquez de Menchaca had distinguished ius gentium naturale (or ius gentium primaevum) from ius gentium secundarium. ${ }^{73}$ The introduction of a 'natural international law' loosened up the relationship between the two layers of international law, allowing for a more independent development of positive international law. However, the actual problem of defining the proper function of natural law in relation to international law was not solved by Vasquez's approach of adding yet another layer to the concept of international law. Leibniz rejected the idea of a ius gentium naturale for two reasons. First, there is only one 'indivisible' natural law that, for Leibniz, is essentially a 'law of reason' or recta ratio. ${ }^{74}$ Second, natural law, for Leibniz, is not group related, it does not have nations or states as addressees. ${ }^{75}$ Heinhard Steiger, thus, correctly holds that ius naturae for Leibniz does

\footnotetext{
${ }^{69}$ Similarly, Steiger, supra note 56, at 110.

70 The content of natural law will be discussed in Part 4 in this article.

${ }^{71}$ Bunge, 'Francisco de Vitoria: A Redesign of Global Order on the Threshold of the Middle Ages to Modern Times', in Kadelbach, Kleinlein and Roth-Isigkeit, supra note 1, 38, at 42.

${ }^{72}$ Steiger, supra note 56, at 109 (with further references).

${ }^{73}$ Ibid.. On this distinction, see Thier, 'Historische Semantiken von ius gentium und "Völkerrecht"', in T. Altwicker, F. Cheneval and O. Diggelmann (eds), Völkerrechtsphilosophie der Frühaufklärung (2015) 29, at 4041.

${ }^{74}$ See Busche, Leibniz' Weg ins perspektivische Universum (1997), at 208 (pointing to Leibniz's conception of equity, which is an essential part of his natural law conception demanding a certain type of proportionality).

${ }^{75}$ See E. Cassirer, Leibniz' System in seinen wissenschaftlichen Grundlagen (1902), at 450 (stating that 'above the particular natural forms of social life, however, for Leibniz, as for Grotius, is the ethical guiding principle of the "community of rational beings": The principle of right is the welfare of the totality: the totality must not be thought of as represented by individuals or by certain groups of individuals, but it includes all the members of the "god-state" and the republic of the universe') (translated by the author).
} 
not exhibit a specific international law-related content. ${ }^{76}$ For Leibniz, the primary function of natural law in relation to ius gentium is that of providing a 'compass' for positive law. ${ }^{77}$ The crucial passage in Leibniz's Praefatio Codicis Juris Gentium Diplomatici runs as follows: ‘The basis then of international law is the same natural law whose principles I made clear a little earlier. ${ }^{78}$ Here, the interpretation of the term 'basis' is decisive. Unlike Vitoria, Leibniz believes that norms of positive international law do not directly flow from natural law. Natural law does not function as a basis for positive international law in any substantive sense of the term. To Leibniz, this must have been evident. First, as will be explained below, natural law for Leibniz consists of highly abstract principles in need of concretization that are compatible with a variety of regulatory designs and regulatory content. ${ }^{79}$ Furthermore, as a lawyer, Leibniz knew that concrete legal questions are hard to solve satisfactorily on the basis of highly abstract principles alone. Leibniz unequivocally holds that positive international law is variable with time and place. ${ }^{80}$ As his collection of international treaties in the Codex Juris Gentium Diplomaticus exemplifies, '[i]t is not necessary that this be the agreement of all peoples or for all times; for there have been many cases in which one thing was considered right in India and another in Europe, and even among us it has changed with the passage of centuries. ${ }^{81}$ Thus, there can only be a 'soft' determination (if at all) of the content of positive international law by natural law. Second, a 'hard' connection between positive and natural law is excluded because the enactment of positive law requires not only knowledge about the 'eternal right of rational nature' (necessary truths) but also an act of imperfect judgment on matters of contingency. While Leibniz believes that there is progress in the art of human law-making, it will never attain the level of perfection. Improving international law-making is a central goal for Leibniz's

\footnotetext{
${ }^{76}$ Steiger, supra note 23, at 438. Instead, natural law is conduct related in the sense that Leibniz expresses the content of natural law in the form of three 'commands' concerning just actions. See, in detail, Part 4 in this article. ${ }^{77}$ The 'compass' metaphor can be found in Leibniz, 'Nova Methodus discendae docendaeque Jurisprudentiae', in DAWB (ed.), Gottfried Wilhelm Leibniz: Sämtliche Schriften und Briefe (1990), vol. 6, part 1, 259, at 341.

${ }^{78}$ Leibniz, supra note 25, at 175; Leibniz, supra note 35, at 74: 'Basis igitur juris faecialis inter Gentes ipsum naturae jus est.'

${ }^{79}$ One may consider the natural law element of ius strictum as an exception. As will be outlined in greater detail below, its 'do-no-harm' principle stipulates an obligation not to harm or damage others. This negative obligation may be considered sufficiently concrete in order to directly derive rules of conduct from the principle. See Busche, supra note 74, at 212 note 539 (arguing that Leibniz aims at identifying 'objective rules of conduct' with the ius strictum).

${ }^{80}$ Leibniz, supra note 25, at 175 (discussing the 'institutions of international law, which changes [sic] according to time and place'); Leibniz, supra note 35, at 74: 'Huic Gentium placita inaedificata sunt, variablia temporibus locisque.'

${ }^{81}$ Leibniz, supra note 25, at 174.
} 
collection of treaty law in the Codex Juris Gentium Diplomaticus. ${ }^{82}$ Third, the impossibility of inferring positive law from natural law also follows from Leibniz's understanding of human freedom; in the field of human action, Leibniz excludes logical or metaphysical necessity. ${ }^{83}$ Finally, Leibniz himself does not describe the relationship between natural and positive international law in the Praefatio Codicis Juris Gentium Diplomatici in terms of a logical operation but, rather, as one that involves construction. ${ }^{84}$ The norms of positive international law, in this conception, must be considered as mere approximations of the abstract ideals formulated by natural law. In sum, natural law as a 'compass' for positive international law means that it provides the right direction, allowing for progress in the project of perfecting international law but leaving considerable room for variation regarding the specific content of legal rules.

However, the compass metaphor does not exhaust the functions of natural law in relation to positive (international) law. Importantly, natural law also acts as a constraint or benchmark for positive law. ${ }^{85}$ In his mature work, the Meditation on the Common Concept of Justice (circa 1702-1703), Leibniz, disagreeing with Hobbes, distinguishes between 'right' and 'law': 'The error of those who have made justice dependent on power comes in part from confounding right and law. Right cannot be unjust, it is a contradiction; but law can be. For it is power which gives and maintains law; and if this power lacks wisdom or good will, it can give and maintain quite evil laws. ${ }^{86}$ This quote clearly marks the anti-voluntarism of the older Leibniz who rejected legal positivism. As will be argued in more detail below, natural law (especially its aequitas element) always also serves as a standard that allows the evaluation of positive legal norms. ${ }^{87}$ In international relations, 'treaties' and 'custom' substitute 'laws', and, therefore, these sources of law also can be unjust if they violate natural law. ${ }^{88}$

Finally, (the later) Leibniz views natural law as the source of the normativity of positive international law. 'Basis', thus, also means that the existence of natural law ensures the validity or bindingness of positive international law in the sense of safeguarding its normative force for

\footnotetext{
${ }^{82}$ See Leibniz, supra note 35, at 55; see also Leibniz, 'Excerpta Ex Epistola VI: Calendarium Martii (1693)', in DAWB (ed.), Gottfried Wilhelm Leibniz: Sämtliche Schriften und Briefe (1692-1694) (2004), vol. 4, part 5, 5, at 30.

${ }^{83}$ Liske, supra note 16 , at 127.

${ }^{84}$ See Leibniz, supra note 35, at 74; Leibniz, supra note 25, at 175: 'On it [natural law] are founded the institutions of international law.'

${ }^{85}$ See Cassirer, supra note 75 , at 450.

${ }^{86}$ Leibniz, supra note 25 , at 50.

${ }^{87}$ See Busche, supra note 74, at 212, n. 539.

${ }^{88}$ The important question of the consequences of a manifestly unjust international legal rule is not discussed by Leibniz.
} 
the 'personae jure gentium' as its subjects. This is only seemingly contradictory to Leibniz's statement in the Praefatio Codicis Juris Gentium Diplomatici when he writes about the 'voluntary law of nations, originating in the tacit consent of peoples'. ${ }^{89}$ An exact translation is crucial at this point. 'Consensu recepto', which is the wording in the Latin original, means 'approved' or 'backed' by consensus; it does not mean 'validated' by consensus. ${ }^{90}$ Grounding the validity of law in the will of the citizens or, in the case of international law, in the will of the peoples would be incompatible with the anti-voluntarism of (the older) Leibniz. Insofar as the ius gentium voluntarium entails obligations for sovereigns, their force of law must be considered as being grounded in natural law. Ultimately, for Leibniz, any legal obligation also that by positive law - is grounded in a moral obligation. ${ }^{91}$ Formally, the normativity of positive international law is safeguarded by the principle of pacta sunt servanda, which has been considered a principle of natural law at least since Grotius. ${ }^{92}$ In a substantive sense, for Leibniz, the source for the bindingness of positive international law - the condition for the possibility of obligations - cannot be of a contractual nature. ${ }^{93}$ Rather, the normative force of positive international law exists in the agent's recognition of his or her moral quality. ${ }^{94}$ Leibniz, thus, once again follows Grotius in defining law as qualitas moralis. ${ }^{95}$ Thus, while the (factual) existence and the content of positive international law are dependent upon the will or consent of the peoples (or sovereigns), its normativity derives from natural law. It is important to once more stress the difference in the conceptions of normativity of Leibniz and Hobbes: Leibniz's conception, in contrast to that of Hobbes, posits a natural (that is, not contractually institutionalized) legal order between the personae jure gentium, which entails legal obligations (and not merely empty rights) and ensures the validity of positive legal norms 'created' by the will or the consent of the sovereigns.

\footnotetext{
${ }^{89}$ Leibniz, supra note 25 , at 174; Leibniz, supra note 35, at 64: '[T] acito populorum consensu receptor.'

${ }^{90}$ Note the difference to Leibniz's statement in the early work of Nova Methodus that the positive 'law derives its validity from the consent of the people'. G.W. Leibniz, Frühe Schriften zum Naturrecht (2003) 26, at 70: '[L]egem ex conventione populi valere' (translated by the author).

${ }^{91}$ See Leibniz, supra note 25, at 170-171; Leibniz, supra note 35, at 60-61.

${ }^{92}$ See Durst, supra note 38, at 223 (stating that Leibniz does make this connection more explicit). Examining historical practice, Leibniz is, however, sceptical of the actual effectiveness of that principle. See Leibniz, supra note 25 , at 165-166 (and even allows for exceptions). I am grateful to an anonymous reviewer for this point.

${ }^{93}$ See Liske, supra note 16, at 190.

${ }^{94}$ Leibniz, supra note $25,170-171$ : 'Right is a kind of moral possibility, and obligation a moral necessity.' On this, see Johns, 'The Grounds of Right and Obligation in Leibniz and Hobbes', 62 Review of Metaphysics (2009) 551, at 563: 'Leibniz does not speak of obligations as deriving from a law, as either a dictate of reason, a law of instinct, of a sovereign, or of God. They derive from one's moral-rational capacity, that is, from the moral possibility of a rational substance to perform just actions.'

${ }_{95}$ Zarka, 'The Invention of the Subject of the Law', 7 British Journal for the History of Philosophy (1999) 245, at 258 .
} 


\section{Ius Strictum, Aequitas and Pietas in International Law: Perfecting International Law}

While natural law, of itself, in Leibniz's conception of international law has no specific international legal content (by not being group related but, rather, conduct related), the principles of natural law are nevertheless of relevance for the construction of law beyond the state and the evaluation of positive international legal norms. Leibniz's early work - the Nova Methodus - already contains his full conception of natural law - his so-called natural law trilogy - distinguishing between three 'stages' or 'principles': strict right (ius strictum), equity (aequitas or caritas) and piety or probity (pietas or probitas).$^{96}$ Leibniz derives his natural law trilogy from a single sentence in the Roman Digest: 'The precepts of right (iuris) are these: live honorably, do not harm another, give to each his own. ${ }^{97}$ What is the meaning of these 'principles' in the context of international law?

Leibniz fleshes out the first stage of natural law - strict right (ius strictum) - in his Nova Methodus. The meaning of ius strictum is individual liberty. Consequently, ius strictum contains two 'basic, inalienable rights': first, the 'liberty right' (ius libertatis), which is defined as 'the right to my body, whose subject I am', and, second, what he calls 'faculty' (facultas), which concerns the right to acquire and to make use of things. ${ }^{98}$ This is the right to selfpreservation, familiar from, for example, Hobbes. However, in a striking difference to Hobbes, Leibniz's right to self-preservation does not entail a natural right to overpower another person, even if one has the capacity to do so or if it is beneficial to one's own interests. ${ }^{99}$ Of greater importance than Hobbes is the immediate influence of Grotius who had defined 'law' in its strict sense as competence (facultas). ${ }^{100}$ The legal relationship on the level of ius strictum is one of formal (arithmetical) equality - everyone is to be treated equally by everyone else. ${ }^{101}$ As already stated, ius strictum is operationalized by the rule of 'do no harm'. ${ }^{102}$ In other words, the do-no-harm principle is the conduct-related interpretation of ius strictum. It entails a negative obligation of abstaining from harming others or inflicting damage on what is rightfully

\footnotetext{
${ }^{96}$ See Leibniz, supra note 90, at 78. In the Praefatio Codicis Juris Gentium Diplomatici, Leibniz reiterates this classification. Leibniz, supra note 25, at 171-172.

${ }^{97}$ Digest 1.1.10 (quotation taken from Johns, supra note 3, at 14).

98 Translation by Johns, supra note 3, at 154; for the original Latin text, see Leibniz, supra note 90, at 48.

${ }^{99}$ Johns, supra note 3, at 14-15.

${ }^{100}$ On Grotius, see Zarka, supra note 95, at 248 (also on power, potestas, as a component of competence, facultas, which is, in turn, sub-divided into the power over oneself, libertas, and the power over others, patria potestas). See also Zarka for tracing the idea of ius strictum to Suarez.

101 Johns, supra note 3.

${ }^{102}$ Leibniz, supra note 90, at 78; Leibniz, supra note 35, at 62.
} 
theirs. ${ }^{103}$ In this interpretation, the do-no-harm principle essentially aims at the preservation of life, liberty and property of the individual. Thus, it is directed at the preservation of individual, private goods (bonum privatum). ${ }^{104}$ In the context of international law, it is easy to see that the do-no-harm principle prohibits aggression or unjust use of force against other sovereigns. Leibniz explicitly draws this conclusion in the Preafatio Codicis Juris Gentium Diplomatici: 'The precept of mere or strict right is that no one is to be injured, so that he will not be given a motive for legal action within the state, nor outside the state a right to war. ${ }^{105}$ In the context of international relations, thus, ius strictum entails the obligation of all sovereigns to preserve international peace by commanding the non-violation of the rights of others independently from considerations of their own benefit or physical capacity. ${ }^{106}$ In a modern interpretation, one could argue that Leibniz's ius strictum on the international level resembles the principles of non-aggression, sovereign equality and territorial integrity. ${ }^{107}$

Leibniz calls the second stage of natural law 'equity' (aequitas). In Leibniz's conception of natural law, 'equity' does not concern 'private goods' (or interests) so much as it relates to the 'public good' (bonum commune) ${ }^{108}$ Whereas 'strict right' pertains to legal relationships between individuals (claims and corresponding obligations), 'equity' extends the scope of natural law to legal relationships within a community. The meaning of aequitas, according to Leibniz, is 'proportionality or ratio between two or more rights' claims' ${ }^{109}$ It is operationalized in the positive obligation to 'give each his own' (suum cuique tribuere). ${ }^{110}$ Other than the negative obligation contained in ius strictum, obligations of 'equity' are never absolute; obligations of 'equity' are conditioned upon considerations of 'merit' and 'proportion'. ${ }^{111}$ Aequitas is not a 'right', and there cannot be a claim to 'equity', as Leibniz

\footnotetext{
${ }^{103}$ On these two dimensions of ius strictum, see Busche, supra note 74, at 205.

${ }^{104}$ See Busche, 'Einleitung', in Leibniz, supra note 90, at 72.

${ }^{105}$ Leibniz, supra note 25 , at 172 .

${ }^{106}$ Leibniz, supra note 35, at 62: 'Et jus quidem 30 merum sive strictum nascitur ex principio servandae pacis'; Leibniz, supra note 25, at 173: 'Simple or strict right is born of the principle of the conservation of peace.'

${ }^{107}$ See Goebel, 'The Equality of States', 23 CLR (1923) 247, at 276 (crediting Leibniz for being the first to develop a 'modern jurisprudence of the conception of equality in international law').

108 See Busche, supra note 74, at 208-209: 'Because the purpose of aequitas [equity] is the promotion of the common good by a performance-motivating division of duties and rights benefiting the community, it includes the jus publicum or jus societatis') (translated by the author). Note that I do not use the terminology of 'private' and 'public' goods in the technical sense familiar from economics but, rather, in the normative sense differentiating between the type of interests that are protected.

${ }^{109}$ Leibniz, supra note 90, at 80: 'Aequitas seu aequalitas, id est, duorum pluriumve ratio vel proportio consistit.' ${ }^{110}$ Ibid., at 80.

${ }^{111}$ Leibniz, supra note 35, at 62; Leibniz, supra note 25, at 172: '[O]nly so far as befits each one or as much as he deserves; for it is impossible to favor everyone.'
} 
says, unless elements of 'equity' are institutionalized in the positive law. ${ }^{112}$ Leibniz gives the following examples on what follows from 'equity': 'equity' requires that 'no murderous war is waged on him who injures me, but rather restitution'; it demands the 'admission of arbitrators' (for reasons of impartial conflict solution) and it demands individuals to 'help those in distress'. ${ }^{113}$ Just like 'strict right', aequitas also ultimately serves the preservation of (public) peace. But it does so through other means - namely, through a fair distribution of benefits and burdens. Unfortunately, Leibniz himself did not give any hints as to how aequitas would apply to international relations and international law. However, some equity rules can easily be transposed to the international level - for example, in cases of injury, aequitas demands resorting to non-forcible counter-measures such as a restitution claim. ${ }^{114}$ Also, Leibniz's idea to settle conflicts by arbitration is, of course, of practical relevance in international law. ${ }^{115}$ Finally, aequitas as an obligation to help those in distress within the limits of reasonableness is also applicable to international relations. For example, facilitating international cooperation in cases of humanitarian catastrophes is a core purpose of the United Nations today. ${ }^{116}$ For these reasons, Thomas Kleinlein is correct in his analysis that one may view Leibniz's conception of international law as one of the 'roots' of contemporary constitutionalism. ${ }^{117}$ If elements of 'equity' are transposed into positive international law (for example, in the form of secondary rules of responsibility like those on restitution or distress) or institutionalized (for example, in the form of arbitrators), a legal (and not merely a political) community of sovereigns becomes stabilized over time. ${ }^{118}$ In sum, Leibniz's idea of aequitas - that is, to serve the bonum commune by institutionalizing proportionality - not only presents a cunning interpretation of the concept of 'equity' but also spells out an innovative interpretation of the idea of publicness, with relevance to the domestic as well as the international sphere.

\footnotetext{
112 Leibniz, supra note 90 , at 80.

${ }^{113}$ Ibid., at 80. On international 'arbitration' and 'mediation' in Leibniz's work, see Blank, 'Leibniz and the Early Modern Controversy over the Right of International Mediation', in W. Li (ed.), 'Das Recht kann nicht ungerecht sein ...': Beiträge zu Leibniz' Philosophie der Gerechtigkeit (2015) 117.

114 See, today, International Law Commission, 'Draft Articles on Responsibility of States for Internationally Wrongful Acts, with Commentaries', 2(2) ILC Yearbook (2001), Art. 50(1)(a), at 131.

115 See Brower, 'Arbitration', in Max Planck Encyclopedia of Public International Law, available at www.mpepil.com. In Leibniz's times, the previously important institution of 'dispute settlement' by the pope (which bears a certain 'family resemblance' with arbitration) had ceased to be in use (at para. 11).

${ }^{116}$ Charter of the United Nations, Art. 1(3).

${ }^{117}$ Kleinlein, supra note 24, at 261-271 (focusing on Leibniz's conception of the civitas dei).

${ }^{118}$ In his correspondence with the Abbé de St Pierre, Leibniz mentions international dispute settlement as a way of rational government. See Leibniz, supra note 25, at 178.
} 
The final stage of natural law is called 'piety' (pietas) or 'probity' (probitas). ${ }^{119}$ Pietas relates neither to private nor to public goods but, rather, to the 'universal good' ${ }^{120}$ For Leibniz, who was a believing Christian, the 'universal good' consists in the preservation of God's creation. ${ }^{121}$ It is operationalized in the command of 'living honestly' or 'piously' (honeste vivere). ${ }^{122}$ Hubertus Busche characterizes Leibniz's conception of pietas as the sense of responsibility of the religious cosmopolitan, for whom the kingdom of God, the civitas dei, has already commenced in the civitas terrena. ${ }^{123}$ Leibniz's conception of pietas rests upon the assumption of the existence of God and the immortality of the soul, and Leibniz grants both. ${ }^{124}$ In Kantian terminology, while the first two stages of natural law concern the 'legality' of human conduct (that is, the conformity of acts with the principles of strict right and equity), 'piety' pertains to questions of 'morality' (that is, acting for the right reasons). ${ }^{125}$ Pietas, thus, primarily relates to motivational issues. From the perspective of human agency, there is also a supererogatory element to pietas; in some situations, pietas requires us to 'hold this life itself and everything that makes it desirable inferior to the great advantage of others, and that we should bear the greatest pains for those near us'. ${ }^{126}$ Pietas, therefore, is associated with the 'charity of the wise', Leibniz's famous definition of justice. ${ }^{127}$ Finally, pietas also means the perfection of the other two stages of natural law. ${ }^{128}$ Pietas, which is the ultimate stage of natural law, reflects a 'comprehensive morality' in which 'all conflicts which arise from the emergence of competing sources of obligation are carried out and mediated'. ${ }^{129}$ The need for this final stage of natural law indicates that, according to Leibniz, the existence of rules for acting - ius strictum, aequitas and positive law - is not sufficient; ultimately, acting justly requires acting for the right reasons by each individual. In other words, it is the morality of the individual that

\footnotetext{
${ }^{119}$ Leibniz, supra note 35, at 62; Leibniz, supra note 25, at 172.

120 See Busche, supra note 104 , at 72.

${ }^{121}$ Leibniz, supra note 90 , at 82.

${ }^{122}$ Leibniz, supra note 35, at 62; Leibniz, supra note 25, at 172.

${ }^{123}$ Busche, supra note 74, at 211 (translated by the author).

${ }^{124}$ Leibniz, supra note 35, at 62; Leibniz, supra note 25, at 173: 'In order really to establish by a universal demonstration that everything honorable is useful and everything base is damned, one must assume the immortality of the soul, and God as ruler of the universe.'

${ }^{125}$ See Busche, supra note 74, at 212, n. 539.

${ }^{126}$ Leibniz, supra note 35, at 63; Leibniz, supra note 25 , at 173.

${ }^{127}$ Ibid., at 171: 'Justice ... will be most conveniently defined ... as the charity of the wise man, that is, charity which follows the dictates of wisdom. ... Charity is a universal benevolence, and benevolence the habit of loving or of willing the good.'

${ }^{128}$ Leibniz sets up a hierarchical order between the three natural law principles: 'Of these stages the following is more perfect than and affirms the preceding; in the event of a conflict, it repeals the lower.' Leibniz, supra note 90, at 78: 'Quorum sequens antecedente perfectior, eumque confirmat, et in casu pugnantiae ei derogat' (translated by the author).

${ }^{129}$ Busche, supra note 74, at 211.
} 
accounts for the justice of actions. This, of course, also holds true for the international level and the interaction between sovereigns, as Leibniz knew from his own experience as diplomat and political advisor. When the French King Louis XIV occupied Strasburg, Leibniz wearily writes in his Mars Christianissimus (1683): '[A]ll judicious people have judged that, after this, it would be useless to rely on the rules of right and on the laws of honor; that conscience, good faith, and the law of nations are cruel terms and vain shadows, since they no longer look for even a pretext for violence.' 130

It is only with difficulty that Leibniz's idea of pietas can be brought to bear in presentday international law. However, it is clear that the scope of pietas as bonum universale, of itself, is not confined by (national) borders but applies universally. It even extends to nonhumans, as Leibniz explicitly states. ${ }^{131}$ The associated questions - 'what is due to a distant people' or 'what is due to distant strangers' - are as relevant today as they were in Leibniz's times marked by colonialism, slave trade and religious wars. ${ }^{132}$ Contemporary international legal theory (at least when conducted by lawyers) usually avoids the justice framing. Questions of international justice are considered as philosophical or ethical problems, which are either viewed as falling outside the sphere of law or as being already embodied in justice-related, specific legal concepts (such as 'human rights' and 'general principles of law').

The idea that law only functions as a limited constraint to acts and that supplementary mechanisms of control are needed was recently taken up by Jan Klabbers in his conception of a 'virtue ethics approach' to international organizations. ${ }^{133}$ Certainly, Klabbers does not argue for applying the notion of an 'honourable life' to international organizations or their agents, but he is concerned with the problem of effective agent control beyond legal constraints. ${ }^{134}$ Thus, Klabbers, avoids a justice framing for his virtue ethics approach to international organizations, using a control or accountability framing instead. ${ }^{135}$ Interestingly, however, Klabbers employs Leibnizian terminology - for example, when claiming that heads of

\footnotetext{
${ }^{130}$ Leibniz, supra note 25 , at 140 . A shift in perspective should be noted; while compliance with natural law is necessary and sufficient for an act to count as ethically 'good', the example of the French King Louis XIV demonstrates that what matters is actual 'good' conduct of responsible rulers, not the merely abstract existence of legal and ethical norms. I am grateful to one anonymous reviewer for the clarification.

${ }^{131}$ Leibniz, supra note 90, at 82: 'According to this principle, it is not even allowed to abuse wild animals and creatures' (translated by the author).

${ }^{132}$ For a recent treatment, see L.E. Lomasky and F.R. Tesón, Justice at a Distance (2015); Glanville, 'The Responsibility to Protect beyond Borders in the Law of Nature and Nations', 28 European Journal of International Law (EJIL) (2017) 1069.

${ }^{133}$ Klabbers, 'Controlling International Organizations: A Virtue Ethics Approach', 8 International Organizations Law Review (2011) 285.

${ }^{134}$ I thank one of the reviewers for pointing this out to me.

${ }^{135}$ Ibid., at 285.
} 
international organizations 'should have a modicum of honesty' or that they should be 'charitable'. ${ }^{136}$ To summarize, pietas is the final stage in Leibniz's natural law trilogy, surmounting the previous two and reflecting morality or universal justice. It can be summarized as a honeste vivere command with universal application.

\section{International Legal Theory in the Best of All Possible Worlds: Three Takeaways for the Contemporary Debate}

Leibniz clearly has something to offer to contemporary international legal theory. What are the takeaway messages for international legal theory? The first takeaway concerns the problem of particularism and universalism in international law. ${ }^{137}$ The present debate concerns the question under which conditions international law can claim to be a truly global legal order (and if these conditions can ever be met). Universalist positions affirm the existence of transnational moral and/or legal principles and, on this basis of common values, tend to allow for a global legal order. In contrast, particularist approaches emphasize that any law, including international law, is formed and applied within heterogeneous, historically and socially diverse contexts, which ultimately puts the possibility of a global legal order into doubt. ${ }^{138}$ Armin von Bogdandy and Sergio Delavalle rightly characterize universalism and particularism as different 'paradigms of order'. ${ }^{139}$ As the above discussion of Leibniz's concept of international law has shown, Leibniz can be characterized as a 'thinker of diversity' ${ }^{140}$ His notion of ius gentium encompasses different conceptual layers with different scope and reach. Furthermore, as Janne Nijman recently has outlined, Leibniz's engagement with other (legal) cultures (for example, the Chinese) allowed the 'possibility of European self-criticism'. ${ }^{141}$

It naturally follows from this engagement with legal diversity that Leibniz recognizes particularist and universalist notions of international law, an amalgamation of, on the one hand,

\footnotetext{
${ }^{136}$ Ibid., at 288-289.

${ }^{137}$ See Dellavalle, 'Beyond Particularism: Remarks on Some Recent Approaches to the Idea of a Universal Political and Legal Order', 21 EJIL (2010) 765; Bogdandy and Dellavalle, 'Universalism and Particularism: A Dichotomy to Read Theories on International Order', in Kadelbach, Kleinlein and Roth-Isigkeit, supra note 1, 482.

${ }^{138}$ Bogdandy and Dellavalle, supra note 138, at 483.

139 Ibid., at 483-484.

${ }^{140}$ Busche, 'Vielfalt als Prinzip der bestmöglichen Welt: Leibniz als Denker der Diversität', in T. Kirchhoff and K. Köchy (eds), Wünschenswerte Vielheit: Diversität als Kategorie, Befund und Norm (2016) 115, at 149: 'The Leibnizian God wants from goodness that as many and different beings exist, live, flourish and enjoy its existence' (translated by the author).

${ }^{141}$ Nijman, supra note 10 , at 229.
} 
time- and place-invariant natural law and, on the other hand, variable, positive international legal norms. To this, divine legal norms are added. As Nijman rightly argues, the diagnosis and analysis of legal diversity turned Leibniz neither into a sceptic nor into an ethical relativist; arguing for mutual toleration, Leibniz believed that the cross-border, cross-cultural exchange of knowledge would ultimately lead to a shared understanding. ${ }^{142}$ Leibniz's conception of international law also allows for, and, indeed requires, differences in the law across place and time. Leibniz's conception is based on the idea of the gradual improvement of international law through a clearer perception of what 'just' law is. In this sense, in Leibniz's conception, diversity, or, in the normative legal context, the plurality of laws, is optimized. ${ }^{143}$ Leibniz is convinced that, over time, by studying historical treaties (answering to contingent historical problems) and Roman law (in search for overarching principles), and by considering the plurality of legal norms in light of common principles, 'better' law-making can be achieved. While today's normative and political dimensions of the problem ('how much legal pluralism under international law') cannot be solved by reference to Leibniz, his philosophy offers a unique conceptual framework - a hermeneutics that may enable a refined understanding of the pressing issue of universalism and particularism.

The second takeaway is of a methodological nature. Leibniz is convinced that scientific endeavour should have a practical impact and that it should always also serve the interests of human beings. This is expressed in his ideal of theoria cum praxi. ${ }^{144}$ Not surprisingly, Leibniz is commemorated not only as the inventor of calculus (apart from Isaac Newton) but also as the inventor of a mechanical calculator. In the present context, Leibniz explicitly states that the scientific engagement with international law ultimately serves the interests of 'peace' (the avoidance of military conflict). ${ }^{145}$ Theoria cum praxi also means that empirical or practical knowledge can inform reflection and ultimately lead to better knowledge. The takeaway message is, bluntly put, that good theory requires a thorough knowledge of practice, just as good practice requires guidance by theory. ${ }^{146}$

The third takeaway relates to Leibniz's insistence that we should not content ourselves with anything short of the legal science of (international) law. The central idea is that

\footnotetext{
142 Ibid., at 229.

${ }^{143}$ Leibniz values the plurality of laws ultimately for instrumental reasons. Ibid., at 243.

144 J. Mittelstraß, Leibniz und Kant (2011), at 113.

${ }^{145}$ See, again, Leibniz, supra note 6, at 140: 'Hujus gentium juris summa ratio est, ut bella evitentur' ['The gist of international law is to avoid wars'] (translated by the author).

${ }^{146}$ On the ways in which practice supports international legal scholarship and vice versa, see Peters, 'Realizing Utopia as a Scholarly Endeavour', 24 EJIL (2013) 533, at 542-544.
} 
international law, as law, must be considered as an integral part of legal science (jurisprudentia), dealing with the methodological study of 'right' and 'wrong' actions. ${ }^{147}$ For Leibniz, treating law as 'legal science' means that it cannot be conducted in isolation from other sciences. He would therefore clearly reject the Kelsenian approach of 'pure law'. In other words, successful legal science can only be an interdisciplinary endeavour. For example, as legal science, it must embrace and be consistent with insights from philosophy and other fields of scholarship. ${ }^{148}$ Accordingly, Leibniz's treatment of international law contains various references to history and theology. Furthermore, conducting law as 'legal science' requires commanding over a large range of methodological and cognitive instruments, which, for Leibniz, included logic and mathematics. ${ }^{149}$ Above all, however, a scientific approach to law must make use of a specific method - namely, formalist reasoning (more geometrico). ${ }^{150}$ Leibniz's idea of a legal science resembles what Anne Peters has called 'multidimensional international legal scholarship'. ${ }^{151}$

In sum, with Leibniz, international legal theory in the best of all possible worlds welcomes legal pluralism (only to optimize it over time), provides theoretical guidance, aims at the improvement of international legal practice and advocates a scientific approach to international law. The image of the lawyer-scientist with whom the responsibility for the advancement of international law rests is best depicted by Leibniz himself (and reads as a recommendation that should be made to all first-year students):

He will settle controversies by his judgment, and, free of tutors at last, in the turf of the sunlit campus, he will fly across the law's wide expanse, perusing the authentic law books, at first the titles and the laws most necessary, then he will gradually add other laws. ... Then, having advanced through the wide sea of controversies, he will observe the customs of the courts and the judgments handed down by the forebears. He will notice those conflicts, disagreements, and dissimilarities between legal systems that are dependent on

\footnotetext{
147 'Jurisprudence is the science of actions, insofar as they are called just or unjust.' Leibniz, supra note 77, at 300: 'Jurisprudentia est scientia actionum quatenus justae vel injustae dicuntur' (emphasis in the original). The English translation is taken from Johns, supra note 3, at 6.

148 Artosi and Sartor, supra note 3, at 644.

${ }^{149} \mathrm{Ibid}$., at 4 (with further references). On 'Jurisprudence as Geometry: Leibniz's Combinatorial Approach to Law', see, importantly, Artosi, Pieri and Sartor, 'Introduction', in A. Artosi, B. Pieri, and G. Sartor (eds), Leibniz: Logico-Philosophical Puzzles in the Law: Philosophical Questions and Perplexing Cases in the Law (2013) 13, at 25-26.

${ }^{150}$ See Liske, supra note 16, at 15 (stating that more geometrico means 'in the style of a Euclidean deductive axiomatized system, to derive all propositions from as few principles as possible by means of definitions') (translated by the author).

${ }^{151}$ Peters, supra note 146, at 545-549.
} 
national character and on the differences among states. And he will learn to deduce, with unbroken connection, firm demonstrations from the unchanging principles of natural law and from public interest, and to cut, with the sword of unvanquished science, the empty subtleties and laughable allegations of the practitioners of law, and the tangled knots deriving from the doctors' purported authority and inappropriate use of brocards. This I will call a true philosopher of law, a priest of justice, and an expert in the law of nations and in what depends on it, and in both civil and divine law. ${ }^{152}$

${ }^{152}$ Leibniz, supra note 77, at 362 (translation taken from Artosi and Sartor, supra note 3, at 652 ) [emphasis in the original]. 